\title{
CORRELATION BETWEEN CERVICAL SAGITTAL ALIGNMENT AND FUNCTIONAL CAPACITY IN CERVICAL SPONDYLOSIS
}

\author{
CORRELAÇÃO ENTRE ALINHAMENTO SAGITAL CERVICAL E CAPACIDADE FUNCIONAL \\ NA ESPONDILOSE CERVICAL
}

\author{
CORRELACIÓN ENTRE ALINEACIÓN SAGITAL CERVICAL Y CAPACIDAD FUNCIONAL \\ EN LA ESPONDILOSIS CERVICAL
}

Marcel Machado da Motta ${ }^{1}$, Raphael de Rezende Pratali', Carlos Eduardo Algaves Soares de Oliveira1

1. Hospital do Servidor Público Estadual de São Paulo, Orthopedics and Traumatology Service, São Paulo, SP, Brazil.

\begin{abstract}
Objective: To correlate the radiographic parameters of sagittal cervical alignment with quality of life and functional capacity in patients with cervical spondylosis under conservative treatment. Methods: This is an observational and prospective study in patients with cervical spondylosis under conservative treatment and without indication for surgery. The 52 patients included were divided into three groups: axial pain, radiculopathy, and cervical myelopathy. The radiographic parameters considered were cervical lordosis (CL), cervical sagittal vertical axis (CSVA), T1 slope (TS) and the discrepancy between TS and CL (TS-CL). Quality of life and functional capacity were evaluated by the Neck Disability Index (NDI) questionnaire. Pain was assessed by the Visual Analogue Scale (VAS). The correlation between the radiographic parameters and the clinical scores was evaluated by the Pearson correlations coefficient. Results: There was no difference in cervical radiographic parameters between the three groups. In the total of the sample, the mean value of the CSVA was $17.8^{\circ}\left( \pm 8.3^{\circ}\right), \mathrm{CL}, 22.4^{\circ}\left( \pm 8.8^{\circ}\right)$; TS, $29.3^{\circ}\left( \pm 6.6^{\circ}\right)$, and TS-CL, $7.0^{\circ}\left( \pm 7.4^{\circ}\right)$. Significant inverse correlation $(r=-0.3, p=0.039)$ was observed between NDI and CL, but there was no significant correlation between CL and VAS. CSVA ( $p=0.541$ ), TS $(p=0.287)$ and TS-CL $(p=0.287)$ had no significantly correlated with NDI or VAS. Conclusion: Considering patients with cervical spondylosis not candidates for surgery, the only sagittal parameter that correlated with functional capacity was LC. In these patients, the correlation between cervical alignment and quality of life needs to be better characterized.
\end{abstract}

Keywords: Spondylosis; Neck pain; Lordosis; Postural balance; Quality of life.

\section{RESUMO}

Objetivo: Correlacionar os parâmetros radiográficos do alinhamento sagital cervical com qualidade de vida e capacidade funcional em pacientes com espondilose cervical em tratamento conservador. Métodos: Trata-se de um estudo observacional e prospectivo em pacientes com espondilose cervical e sem indicação de cirurgia. Os 52 pacientes incluídos foram divididos em três grupos: dor axial, radiculopatia e mielopatia cenvical. Os parâmetros radiográficos considerados foram lordose cenvical (LC), eixo vertical sagital cenvical (EVSC), ângulo de inclinação de T1 (AlT1) e discrepância entre inclinação de T1 e lordose cervical (AlT1-LC). A qualidade de vida e a capacidade funcional foram avaliadas por meio do questionário Neck Disability Index (NDI). A dor foi avaliada pela Escala Visual Analógica (EVA). A correlação entre os parâmetros radiográficos e os escores clínicos foi avaliada pelo coeficiente de correlação de Pearson. Resultados: Não houve diferença nos parâmetros radiográficos cervicais entre os três grupos. No total da amostra, a média do EVSC foi de 17, $8^{\circ}\left( \pm 8,3^{\circ}\right)$; da $L C, 22,4^{\circ}\left( \pm 8,8^{\circ}\right)$; do AlT1, 29, $3^{\circ}\left( \pm 6,6^{\circ}\right.$ ) e da AlT1-LC, $7,0^{\circ}\left( \pm 7,4^{\circ}\right)$. Obsenou-se correlação inversa significante $(r=-0,3, p=0,039)$ entre NDI e LC, mas não houve correlação significante entre LC e EVA. EVSC ( $p=0,541)$, AlT1 ( $p=0,287)$ e AlT1-LC ( $p=0,287)$ não tiveram correlação significante com NDI ou EVA. Conclusão: Considerando pacientes com espondilose cenvical não candidatos à cirurgia, o único parâmetro sagital cenvical que se correlacionou com capacidade funcional foi LC. Nesses pacientes, a correlação entre o alinhamento cervical e qualidade de vida precisa ser mais bem caracterizada.

Descritores: Espondilose; Cervicalgia; Lordose; Equilíbrio postural; Qualidade de vida.

\section{RESUMEN}

Objetivo: Correlacionar los parámetros radiográficos de la alineación sagital cervical con calidad de vida y capacidad funcional en pacientes con espondilosis cervical en tratamiento consenvador. Métodos: Se trata de un estudio observacional y prospectivo en pacientes con espondilosis cervical i sin indicación de cirugía. Los 52 pacientes incluidos fueron divididos en tres grupos: dolor axial, radiculopatía y mielopatía cervical. Los parámetros radiográficos considerados fueron lordosis cervical (LC), eje vertical sagital cervical (EVSC), ángulo de inclinación de T1 (AlT1) y discrepancia entre AlT1 y LC (AIT1-LC). La calidad de vida y la capacidad funcional fueron evaluadas mediante el cuestionario Neck Disability Index (NDI). El dolor se evaluó por la Escala Visual Analógica (EVA). La correlación entre los parámetros radiográficos y los escores clínicos fue evaluada por el coeficiente de correlación de Pearson. Resultados: No hubo diferencia en los parámetros radiográficos cervicales entre los

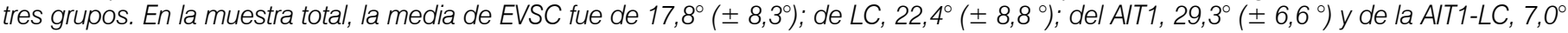
$\left( \pm 7,4^{\circ}\right)$. Se observó una correlación inversa significativa $(r=-0,3, p=0,039)$ entre NDI y LC, pero no hubo correlación significativa entre LC y EVA. EVSC $(p=0,541)$, AlT1 $(p=0,287)$ y AlT1-LC $(p=0,287)$ no tuvieron correlación significativa con NDI o EVA. Conclusión: Considerando pacientes con espondilosis cervical no candidatos a la cirugía, el único parámetro sagital cervical que se correlacionó con capacidad funcional fue LC. En estos pacientes, la correlación entre la alineación cervical y la calidad de vida debe ser mejor caracterizada.

Descriptores: Espondilosis; Dolor de cuello; Lordosis; Balance postural; Calidad de vida. 


\section{INTRODUCTION}

The cervical region is the spinal segment with the most mobility, in addition to being responsible for support of the weight of the head, and is susceptible to a series of pathologies associated with significant compromise to quality of life and functional disability. ${ }^{1,2}$ Physiologically, the cervical segment functions in lordosis and changes to this curvature are commonly observed in patients with cervical pathologies. ${ }^{2-5}$

Loss of the sagittal alignment of the spine is well-established as a determinant of pain and functional disability in adults. ${ }^{6-8}$ The correlation between sagittal imbalance, represented by a plumb line from C7 (sagittal vertical axis), and compromised quality of life, represented by worse scores obtained from questionnaires, has been demonstrated by various studies, as well as by better postoperative clinical results obtained when alignment is restored..$^{9-11}$ It has also been shown that in addition to the analysis of overall sagittal alignment, i.e., of the sagittal vertical axis, the pelvis plays a fundamental role in spine alignment, functioning as a tool to compensate for the loss of overall sagittal alignment and also correlating with quality of life indicators.8,12,13

Recently, the importance of the sagittal alignment of the cervical segment of the spine has been demonstrated, and that deformity of the cervical spine is associated with pain, functional disability, and even the severity of cervical myelopathy. ${ }^{1,2,14-17}$ Standing out among the radiographic parameters most used to evaluate cervical alignment are cervical lordosis (CL) as defined by the Cobb method, based on lines parallel to the lower terminal plates of $\mathrm{C} 2$ and $\mathrm{C} 7 ;^{18}$ the cervical sagittal vertical axis (CSVA), measured by the perpendicular distance between a plumb line drawn from $\mathrm{C} 2$ and the posterior-superior aspect of the vertebral body of $\mathrm{C}^{2}$; and the discrepancy between the T1 slope (TS) and cervical lordosis (CL), calculated by the arithmetic expression TS-CL, which, according to some authors, acts as the cervical equivalent to the discrepancy between pelvic incidence and lumbar lordosis for the lumbar spine. ${ }^{19}$

Even though the correlation between such radiographic parameters of cervical sagittal alignment with quality of life and postoperative outcomes in patients submitted to surgical treatment is well-established, ${ }^{15,20,21}$ there is a scarcity of evidence in the literature of any correlation between cervical sagittal parameters and loss of quality of life or functional disability in patients in conservative treatment. Thus, the objective of this study is to evaluate and correlate radiographic parameters of cervical sagittal alignment with quality of life and functional disability indicators in patients with cervical spondylosis in a conservative outpatient treatment regimen who are not candidates for surgical treatment.

\section{METHODS}

This is an observational, prospective study, approved by the Institutional Review Board (IRB) of the responsible service (opinion no. 1.445.245). Participating in the study were patients attended at the outpatient spine pathology clinic of the same service, all having filled out the Informed Consent Form approved by the IRB. Individuals over 18 years of age with a diagnosis of cervical spondylosis undergoing a conservative treatment regime and who were not candidates for surgery were included. Individuals with spinal pathologies other than spondylosis (such as neoplasias, trauma, and congenital deformities), prior spine surgeries, patients with neurological disease, psychiatric conditions that compromise their understanding of the study, and patients who were indicated or opted for surgical treatment of their cervical spine condition were excluded. The patients were divided into three groups by clinical profile: Axial pain, Radiculopathy and Cervical myelopathy.

Lateral total spine radiographs of the patients were taken in a standing position with their eyes fixed on the horizon. Only exams that permitted adequate visualization from the base of the skull to the first thoracic vertebra (T1) were considered. The digitalized images obtained were analyzed using Surgimap Spine software (Nemaris Inc., New York, USA) to measure the following radiographic parameters of cervical sagittal alignment: cervical lordosis $(\mathrm{CL})$, cervical sagittal vertical alignment (cSVA), the angle of inclination of T1 (TS), and the difference between the T1 inclination and the cervical lordosis (TS-CL), as illustrated in Figure 1.

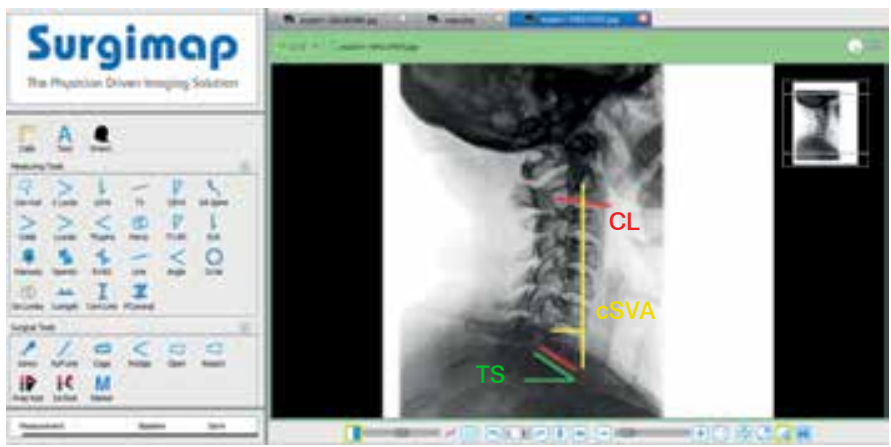

Figure 1. Example of a digitalized image with measurements of the radiographic parameters of interest (cSVA, TS, and CL) using Surgimap Spine software (Nemaris Inc., New York, USA).

Quality of life and desability were evaluated using the Neck disability index (NDI) questionnaire translated and validated for the Portuguese language. ${ }^{22}$ For the evaluation of the intensity of cervical axial pain, the Visual analog scale (VAS) was used, graded from 0 to 10 , where 0 equals the absence of pain and 10 the strongest pain the patient has ever felt. ${ }^{23}$

Statistical analysis was performed using STATA 11 SE software. The normality of the variables was tested by the Shapiro-Wilk test and the correlation analysis was tested by calculating the Pearson correlation coefficient. The comparison of the radiographic parameters between the patients with axial pain, radiculopathy, or myelopathy was conducted by means of the ANOVA test. A significance level of $5 \%$ was considered, therefore the results with a value of $p$ lower than 0.05 were considered to be statistically significant.

\section{RESULTS}

The study included 52 patients with an average age of 60 years, ranging from 24 to 84 years of age with a standard deviation of 12 years. The sample was made up of 38 female patients (73\%) and 14 male patients (27\%). Of the total number of patients analyzed, 43 $(82.7 \%)$ were classified as Axial Pain, 3 (5.8\%) as Myelopathy, and $6(11.6 \%)$ as Radiculopathy. Taking the total sample into account, the average cSVA was $17.8^{\circ}\left( \pm 8.3^{\circ}\right)$, the average $\mathrm{CL}, 22.4^{\circ}\left( \pm 8.8^{\circ}\right)$; the average TS, $29.3^{\circ}\left( \pm 6.6^{\circ}\right)$, and the average TS-CL difference, $7.0^{\circ}\left( \pm 7.4^{\circ}\right)$. Comparing the cervical sagittal alignment parameters in terms of classification by diagnosis, no significant difference was found for any of the parameters studied. (Table 1)

Table 2 shows the study of correlation between the radiographic parameters and the age of the patients of the study. There was a correlation with the cSVA $(r=0.3)$ and the TS $(r=0.3)$, both of them weak, but statistically significant $(p=0.04$ and $p=0.03$, respectively) and a moderate statistically significant correlation ( $r=$ $0.04, p<0.001$ ) with the $\mathrm{CL}$. There was no statistically significant correlation between age and TS-CL. Considering the radiographic cervical sagittal alignment parameters among themselves, there was a moderate correlation $(r=0.4, p=0.004)$ between the cSVA and the TS and between the CL and the TS $(r=0.6$, $p<0.001$ ). (Table 3)

Table 1. Values of the cervical sagittal parameters according to each diagnosis.

\begin{tabular}{c|c|c|c|c|c}
\hline & \multicolumn{4}{|c|}{ Diagnosis } & \\
\cline { 2 - 7 } & $\begin{array}{c}\text { Average } \\
\text { axial pain } \\
\text { (SD) }\end{array}$ & $\begin{array}{c}\text { Average } \\
\text { myelopathy } \\
\text { (SD) }\end{array}$ & $\begin{array}{c}\text { Average } \\
\text { radiculopathy } \\
\text { (SD) }\end{array}$ & $\begin{array}{c}\text { Average } \\
\text { for total } \\
\text { sample (SD) }\end{array}$ & $\mathbf{p}$ \\
\hline CSVA (mm) & $17.8(7.8)$ & $21.4(13.0)$ & $16.7(10.4)$ & $17.9(8.17)$ & 0.723 \\
\hline $\mathrm{CL}$ (degrees) & $22.8(8.5)$ & $23.7(13.0)$ & $18.7(11.9)$ & $21.8(8.4)$ & 0.296 \\
\hline TS (degrees) & $29.0(6.5)$ & $23.3(6.7)$ & $29.3(7.5)$ & $28.7(6.9)$ & 0.409 \\
\hline TS-CL (degrees) & $6.2(7.1)$ & $10.7(2.9)$ & $10.7(10.2)$ & $6.9(7.5)$ & 0.265 \\
\hline
\end{tabular}


The analysis of the intensity of cervical axial pain in the patients, through the VAS, showed an average of $6.8( \pm 2.5)$, considering the total sample. The study of the correlation of the VAS with the cervical sagittal alignment parameters, illustrated in Table 3, did not show any significant correlation of cervical pain with any radiographic parameter $(p>0.05)$. The average score obtained for the NDI questionnaire, considering the total sample, was 39.1 ( \pm 16.5$)$, ranging from 8 to 84 . Table 4 shows the correlation of the NDI score with the radiographic cervical sagittal alignment parameters. There was an inverse correlation of weak intensity $(r=-0.3)$, though statistically significant ( $p=0.039$ ), between the CL and the NDI. (Figure 2) There was no significant correlation between the NDI and any of the other radiographic parameters considered.

Table 2. Correlation of the cervical sagittal parameters with age.

\begin{tabular}{c|c|c}
\hline Variable & \multicolumn{2}{|c}{ Age } \\
\hline CSVA (mm) & Correlation coefficient ( $\mathbf{~}$ ) & $\mathbf{p}$ \\
\hline CL (degrees) & 0.3 & $0.04^{*}$ \\
\hline TS (degrees) & 0.4 & $<0.001^{*}$ \\
\hline TS-CL (degrees) & 0.3 & $0.03^{*}$ \\
\hline${ }^{*}=$ values with statistical significance $(p<0.05)$. & 0.09 \\
\hline
\end{tabular}

Table 3. Values of the correlations ( $r$ ) between the variables studied.

\begin{tabular}{|c|c|c|c|c|c|c|c|}
\hline Variables & $\stackrel{\mathscr{g}}{\leftarrow}$ & 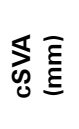 & U & 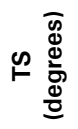 & 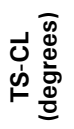 & 蛋 & $\overline{\mathbf{z}}$ \\
\hline Age & - & $0.3^{*}$ & $0.4^{*}$ & $0.3^{*}$ & -0.2 & 0.0 & -0.1 \\
\hline cSVA (mm) & $0.3^{*}$ & - & 0.1 & $0.4^{*}$ & 0.2 & 0.0 & 0.1 \\
\hline CL (degrees) & $0.4^{*}$ & 0.1 & - & $0.6^{*}$ & 0.0 & 0.0 & $-0.3^{*}$ \\
\hline TS (degrees) & $0.3^{*}$ & $0.4^{*}$ & $0.6^{*}$ & - & 0.2 & 0.0 & -0.2 \\
\hline TS-CL (degrees) & -0.2 & 0.2 & $-0.7^{*}$ & 0.2 & - & 0.0 & 0.2 \\
\hline VAS & 0.0 & 0.0 & 0.0 & 0.0 & 0.0 & - & $0.4^{*}$ \\
\hline NDI & -0.1 & 0.1 & $-0.3^{*}$ & -0.2 & 0.2 & $0.4^{*}$ & - \\
\hline
\end{tabular}

Table 4. Correlation of the NDI with cervical sagittal parameters.

\begin{tabular}{c|c|c}
\hline & \multicolumn{2}{|c}{ NDI } \\
\hline & Correlation coefficient (r) & $\mathbf{p}$ \\
\hline cSVA (mm) & 0.1 & 0.541 \\
\hline CL (degrees) & -0.3 & $0.039^{*}$ \\
\hline TS (degrees) & -0.2 & 0.287 \\
\hline TS-CL (degrees) & 0.2 & 0.142 \\
\hline
\end{tabular}

* = values with statistical significance $(p<0.05)$.

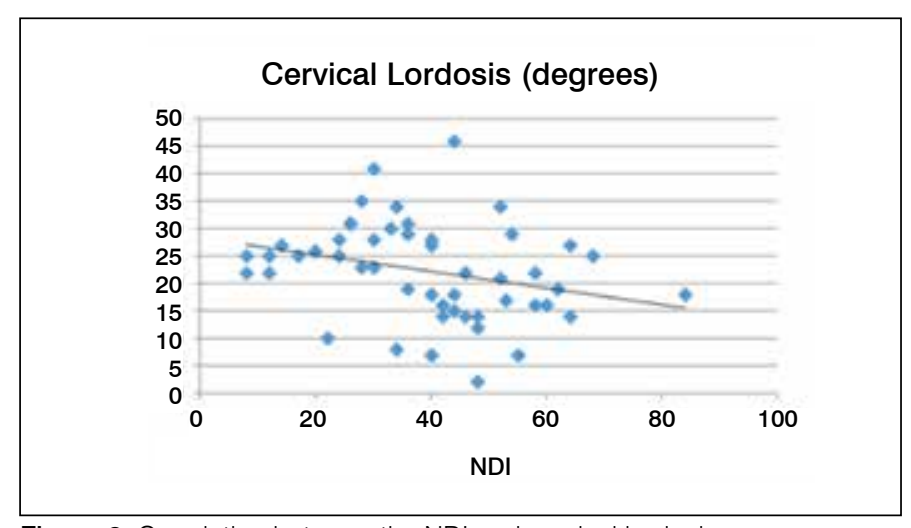

Figure 2. Correlation between the NDI and cervical lordosis.

\section{DISCUSSION}

In the past few years, various studies have tried to correlate spinal sagittal alignment parameters to quality of life, both after surgical procedures and in individuals who did not undergo surgery. ${ }^{24-26}$ More recently, there has been an increase in the number of studies demonstrating that there is also an important correlation between the postoperative outcomes of spine interventions and sagittal parameters. ${ }^{15,20,27}$ However, studies that correlate cervical sagittal parameters with quality of life indicators in patients who were not submitted to surgical treatment are extremely rare. This study analyzed the correlation of these radiographic parameters with indicators of quality of life and functional ability in a sample of patients with cervical spondylosis without an indication for surgical treatment or who opted not to undergo surgical treatment.

Tang et al. ${ }^{15}$ demonstrated the cSVA as an independent predictor of functional outcomes in patients submitted to posterior spinal arthrodesis. Thereafter, the cSVA was associated with worse severity of cervical myelopathy. ${ }^{16}$ In this study, there was no evidence of a correlation between the cSVA and quality of life, although the sample was made up of patients with no indication of surgical treatment or who had opted out of surgery. In addition, only 5.8\% of the patients included had a diagnosis of myelopathy.

Our study results showed a significant inverse correlation between the $C L$ and the NDI: the higher the value of the $C L$, the lower the value obtained from the NDI, i.e., the better the functional ability of the patient. In a recent study, lyer et al. ${ }^{28}$ analyzed the correlation between radiographic sagittal alignment parameters and quality of life in the preoperative period in patients awaiting surgical procedure. An inverse correlation was observed between the CL and the NDI, in that an increase in the CL was also associated with lower NDI values, similar to what was observed in our study. However, in their study, lyer et al. ${ }^{28}$ divided the patients into two groups - myelopathy and radiculopathy - and there was a significant correlation between the radiographic parameters and the NDI in the patients with myelopathy, but not in the patients with radiculopathy. Again, the vast majority of the patients in our study were classified as suffering from axial pain and radiculopathy (94\%), and the minority with myelopathy.

The correlation between the cervical sagittal alignment parameters themselves has been demonstrated in recent studies, ${ }^{1,21,29}$ as well as the role of the cervical-thoracic junction in cervical sagittal alignment, similar to what occurs in alignment of the thoracolumbar spine in correlation to the pelvis. ${ }^{2,13}$ The correlation between the TS and the CL, showing that the amount of $C L$ is influenced by the inclination of the upper plateau of T1 (TS), has been published in the literature $21,29,30$ and was also evident in our study. A significant correlation between the TS and the cSVA was also confirmed, which indicates the important role of the inclination of T1 for all cervical sagittal alignment, as previously demonstrated in the literature. 2,29,30

This study also showed the effect of aging on cervical sagittal alignment. As seen in the results obtained, the TS, the CL, and the cSVA tend to increase with age. Yukawa et al. ${ }^{30}$ published similar results and argued that with age the spine tends to assume positive sagittal alignment, increasing the TS. In order to maintain the ability to look forward, the cervical spine has an increase in the value of cervical lordosis.

The main limitation of this study was the small case series and also the fact that few cases were included (15.3\%) that could be classified as patients with "cervical spine deformity", according to the criteria of the recently published classification system for cervical deformity. ${ }^{31}$ The fact that very few of the patients in the sample did not have indicators for a diagnosis of deformity and that the study only included patients who were not candidates for surgical treatment or who opted for non-surgical treated may suggest that the patients without criteria for deformity are more favorable to non-surgical treatment than patients with cervical spine deformity.

It seems incontestable that cervical alignment is a direct indicator of functional outcomes and of the quality of life following cervical spine arthrodesis and that the existence of a well-established correlation 
between radiographic cervical alignment parameters and quality of life has been demonstrated in patients with myelopathy and cervical spine deformity. However, in patients with cervical spondylosis presenting axial pain and radiculopathy, without myelopathy and without deformity, this correlation has not been well-established.

\section{CONCLUSIONS}

Considering a sample of patients with cervical spondylosis without indications for surgical treatment or who opted for non-surgical treatment, the only radiographic cervical spine alignment parameter that was correlated with quality of life was cervical lordosis. In these patients, presenting axial pain and radiculopathy, without myelopathy and without deformity, the correlation between cervical alignment and quality of life need to be better characterized.

All authors declare no potential conflict of interest related to this article.

CONTRIBUTION OF THE AUTHORS: Each author made significant individual contributions to this manuscript. Study concept and design: MMM and RRP. Data collection and IRB approval: MMM. Data interpretation and analysis: MMM and RRP. Development of the article: MMM. Critical review of the article: RRP. Review of the final version for submission: MMM, RRP, and CEASO.

\section{REFERENCES}

1. Scheer JK, Tang JA, Smith JS, Acosta FL Jr, Protopsaltis TS, Blondel B, et al. Cervical spine alignment, sagittal deformity, and clinical implications: a review. J Neurosurg Spine. 2013;19(2):141-59.

2. Ames CP, Blondel B, Scheer JK, Schwab FJ, Le Huec JC, Massicotte EM, et al. Cervical radiographical alignment: comprehensive assessment techniques and potential importance in cervical myelopathy. Spine (Phila Pa 1976). 2013;38(22 Suppl 1):S149-60.

3. Bost $\mathrm{HC}$ Jr. The curve of the cervical spine: variations and significance. J Manipulative Physiol Ther. 1995;18(4):254

4. McAviney J, Schulz D, Bock R, Harrison DE, Holland B. Determining the relationship between cervical lordosis and neck complaints. J Manipulative Physiol Ther. 2005;28(3):187-93.

5. Hardacker JW, Shuford RF Capicotto PN, Pryor PW. Radiographic standing cervical segmental alignment in adult volunteers without neck symptoms. Spine (Phila Pa 1976). 1997;22(13):1472-80

6. Fu KM Smith JS, Sansur CA Shaffrey Cl. Standardized measures of health status and disability and the decision to pursue operative treatment in elderly patients with degenerative scoliosis. Neurosurgery. 2010;66(1):42-7.

7. Smith JS, Shaffrey Cl, Berven S, Glassman S, Hamill C, Horton W, et al. Improvement of back pain with operative and nonoperative treatment in adults with scoliosis. Neurosurgery. 2009;65(1):86-93.

8. Ames CP, Smith JS, Scheer JK, Bess S, Bederman SS, Deviren V, et al. Impact of spinopelvic alignment on decision making in deformity surgery in adults: a review. J Neurosurg Spine. 2012;16(6):547-64

9. Smith JS, Shaffrey Cl, Fu KM, Scheer JK, Bess S, Lafage V, et al. Clinical and radiographic evaluation of the adult spinal deformity patient. Neurosurg Clin N Am. 2013:24(2):143-56

10. Glassman SD, Bridwell K, Dimar JR, Horton W, Berven S, Schwab F. The impact of positive sagittal balance in adult spinal deformity. Spine (Phila Pa 1976). 2005:30(18):2024-9.

11. Smith JS, Lafage V, Schwab FJ, Shaffrey Cl, Protopsaltis T, Klineberg E, et al. Prevalence and type of cervical deformity among 470 adults with thoracolumbar deformity. Spine (Phila Pa 1976). 2014;39(17):E1001-9.

12. Lafage V, Schwab F, Patel A, Hawkinson N, Farcy JP. Pelvic tilt and truncal inclination: two key radiographic parameters in the setting of adults with spinal deformity. Spine (Phila Pa 1976). 2009;34(17):E599-606.

13. Schwab F, Lafage V, Patel A, Farcy JP. Sagittal plane considerations and the pelvis in the adult patient. Spine (Phila Pa 1976). 2009;34(17):1828-33

14. Villavicencio AT, Babuska JM, Ashton A, Busch E, Roeca C, Nelson EL, et al. Prospective, randomized, double-blind clinical study evaluating the correlation of clinical outcomes and cervical sagittal alignment. Neurosurgery. 2011;68(5):1309-16.

15. Tang JA, Scheer JK, Smith JS, Deviren V, Bess S, Hart RA, et al. The impact of standing regional cervical sagittal alignment on outcomes in posterior cervical fusion surgery. Neurosurgery. 2012:71(3):662-9

16. Smith JS, Lafage V, Ryan DJ, Shaffrey Cl, Schwab FJ, Patel AA, et al. Association of myelopathy scores with cervical sagittal balance and normalized spinal cord volume: analysis of 56 preoperative cases from the AOSpine North America Myelopathy study. Spine (Phila Pa 1976) 2013:38(22 Suppl1):S161-70.

17. Grosso MJ, Hwang R, Mroz T, Benzel E, Steinmetz MP. Relationship between degree of focal kyphosis correction and neurological outcomes for patients undergoing cervical deformity correction surgery. J Neurosurg Spine. 2013:18(6):537-44.

18. Harrison DE, Harrison DD, Cailliet R, Troyanovich SJ, Janik TJ, Holland B. Cobb method or Harrison posterior tangent method: which to choose for lateral cervical radiographic analysis. Spine (Phila Pa 1976). 2000;25(16):2072-8.

19. Hyun SJ, Kim KJ, Jahng TA, Kim HJ. Relationship Between T1 Slope and Cervical Alignment Following Multilevel Posterior Cervical Fusion Surgery: Impact of T1 Slope Minus Cervical Lordosis. Spine (Phila Pa 1976). 2016:41(7):E396-402.

20. Gum JL, Glassman SD, Douglas LR, Carreon LY. Correlation between cervical spine sagittal alignment and clinical outcome after anterior cervical discectomy and fusion. Am J Orthop (Belle Mead NJ). 2012;41(6):E81-4.

21. Lee SH, Kim KT, Seo EM, Suk KS, Kwack YH, Son ES. The influence of thoracic inlet alignment on the craniocervical sagittal balance in asymptomatic adults. J Spinal Disord Tech. 2012;25(2):E41-7.

22. Cook C, Richardson JK, Braga L, Menezes A, Soler X, Kume P, et al. Cross-cultural adaptation and validation of the Brazilian Portuguese version of the Neck Disability Index and Neck Pain and Disability Scale. Spine. 2006;31(14):1621-7.

23. Falvigna A, Teles AR, Braga GL, Barazzetti AO, Lazzaretti L, Tregnago AC. Instrumentos de avaliação clínica e funcional em cirurgia da coluna vertebral. Coluna/Columna. 2011;10(1):62-7.

24. Schwab FJ, Blondel B, Bess S, Hostin R, Shaffrey Cl, Smith JS, et al. Radiographical spinopelvic parameters and disability in the setting of adult spinal deformity: a prospective multicenter analysis. Spine (Phila Pa 1976). 2013:38(13):E803-12.

25. Djurasovic M, Glassman SD. Correlation of radiographic and clinical findings in spinal deformities. Neurosurg Clin N Am. 2007;18(2):223-7.

26. Glassman SD, Berven S, Bridwell K, Horton W, Dimar JR. Correlation of radiographic parameters and clinical symptoms in adult scoliosis. Spine (Phila Pa 1976). 2005;30(6):682-8.

27. Cabraja M, Abbushi A, Koeppen D, Kroppenstedt S, Woiciechowsky C. Comparison between anterior and posterior decompression with instrumentation for cervical spondylotic myelopathy: sagittal alignment and clinical outcome. Neurosurg Focus. 2010;28(3):E15.

28. Iyer S, Nemani VM, Nguyen J, Elysee J, Burapachaisri A, Ames CP, et al. Impact of cervical sagittal alignment parameters on neck disability. Spine (Phila $\mathrm{Pa}$ 1976). 2016;41(5):371-7.

29. Nasreddine MA, Pratali RR, Barsotti CEG, Santos FPE, Oliveira CEA. Alignment of cervica spine on a sample of asymptomatic subjects. Coluna/Columna. 2017;16(1):13-16.

30. Yukawa Y, Kato F, Suda K, Yamagata M, Ueta T. Age-related changes in osseous anatomy, alignment, and range of motion of the cervical spine. Part I: radiographic data from over 1,200 asymptomatic subjects. Eur Spine J. 2012;21(8):1492-8.

31. Ames CP, Smith JS, Eastlack R, Blaskiewicz DJ, Shaffrey Cl, Schwab F, et al. Reliability assessment of a novel cervical spine deformity classification system. J Neurosurg Spine. 2015;23(6):673-83. 